\title{
Modeling the Antecedents of Customer Switching Behaviour in Nigerian Banking Industry
}

\author{
Kabiru Maitama Kura, Nik Kamariah Nik Mat", Abdullahi Hassan Gorondutse, \\ Abubakar Muhammed Magaji, Aminu Yusuf
}

Othman Yeop Abdullah Graduate School of Business, Universiti Utara Malaysia, Sintok, 06010, Malaysia

\begin{abstract}
This study examines the antecedents of customer switching behaviour in Nigerian banking industry. Customer switching behavior in deposit money banks has become an important issue for discussion among the researchers, policy makers and other stakeholders of the banks. From the marketing literature, two antecedents of customer switching behavior were obtained from factor analysis, namely; assurance and empathy. Each of the construct in this study was measured using 7-point scale ranging from 1 strongly disagree to 7 strongly agree: assurance has 5 items, empathy has 4 items, word of mouth and customer switching have 3 items each. One hundred and fifty questionnaires were administered to target respondents of selected customers of deposit money banks in Kano Metropolis in North-Western region of Nigeria. One hundred questionnaires were completed and returned, representing 66.7 percent response rate. We utilized a Structural Equation Modeling (SEM) using SmartPLS 2.0. The findings of this study revealed that there is a significant positive relationship between: assurance and word of mouth communication; empathy and word of mouth communication. The study also found a significant negative relationship between word of mouth communication and customer switching. Meanwhile, the study did not find a significant relationship between: assurance and customer switching; empathy and customer switching. The implication of the findings in the perspective of deposit money banks' customers is discussed.
\end{abstract}

Keywords Customer Switching Behviour, Perceived Service Quality, Assurance, Empathy, Word Of Mouth, Deposit Money Banks, Nigeria

\section{Introduction}

In recent years, Nigerian banking industry has witnessed a remarkable change. Since 2005, which was one year after the Central Bank of Nigeria (CBN) consolidation of the banking industry, competition among the Deposit Money Banks (DMBs) has been increasing due to the customers' financial awareness and high expectation in terms of quality of services they require from banks, Soludo, 2006[1]. For banks to retain their existing customers, understanding the antecedents of customer switching is important. Customer switching is defined as an act of being loyal to one service categories (e.g. banking services), but switch from one service provider (e.g. Union Bank of Nigeria Plc), to another (e.g. First Bank of Nigeria Plc), as a result of dissatisfaction or any other related problems, Keaveney, and Parthasarathy, 2001; Sathish, Kumar, Naveen and Jeevanantham, 2011 ([2],[3]).

Customer switching has become prevalent and a major

* Corresponding author:

drnikuum@gmail.com (Nik Kamariah Nik Mat)

Published online at http://journal.sapub.org/economics

Copyright () 2012 Scientific \& Academic Publishing. All Rights Reserved concern of both service providers and academics. For example, in a global survey of customer behaviour in retail banking, Ernst \& Young[4] reported that worldwide, $36 \%$ of customers have changed their main bank to another in the past two years, and another 7\% of customers are planning to switch to other banks. Dimension of service quality is one of the many important predictors of customer switching. The dimensions of service quality that have been investigated by the researchers over the years include assurance, empathy, reliability, responsiveness and tangibility, Choi, Cho, Lee, Lee and Kim, 2004; Alexandris, Dimitriadis and Markata, $2002 ;([5],[6])$. However, despite the large number of studies that examined effects of service quality dimensions on service switching, to the best of our knowledge little is known on the effects of these dimensions on customer switching in Nigerian banking industry. Thus, the purpose of this study is to examine the causal relationships of selected antecedents of customer switching behaviour in Nigerian banking industry. The remainder of this paper is organized along these lines. In section 2, we conducted a comprehensi ve literature review on the antecedents of customer switching behaviour: dimensions of service quality and word of mouth. In section 3, the research framework, methods, measurement of variables and the results of the study are presented. In the last section, the managerial implications of the study and the 
recommendations for future research are discussed.

\section{Literature Review}

\subsection{Perceived Service Quality}

Perceived service quality is defined as the outcomes of the customer's overall evaluation of the differences between service expectations and the actual service performance, Parasuraman, Berry and Zeithaml, 1985[7]. Perceived servi ce quality is conceptualized as a multidimensional construct consisting of five dimensions, namely; tangibles, reliability, responsiveness, assurance and empathy, Parasuraman et al
[7]. Furthermore, Parasuraman, Zeithaml and Berry, 1988[8] suggested concise definitions for the five dimensions of service quality as follows: (1) tangibles means the appearance of physical facilities, equipment, and the personnel; (2) reliability refers to the ability to render the services promised dependably and accurately; (3) responsiveness refers to the willingness of service provider to help customer and provide them with prompt service; (4) assurance refers to the knowledge and courtesy of personnel and their ability to stimulate trust and confidence; and (5) empathy refers to the caring, individualized attention the firm accorded to its customers.

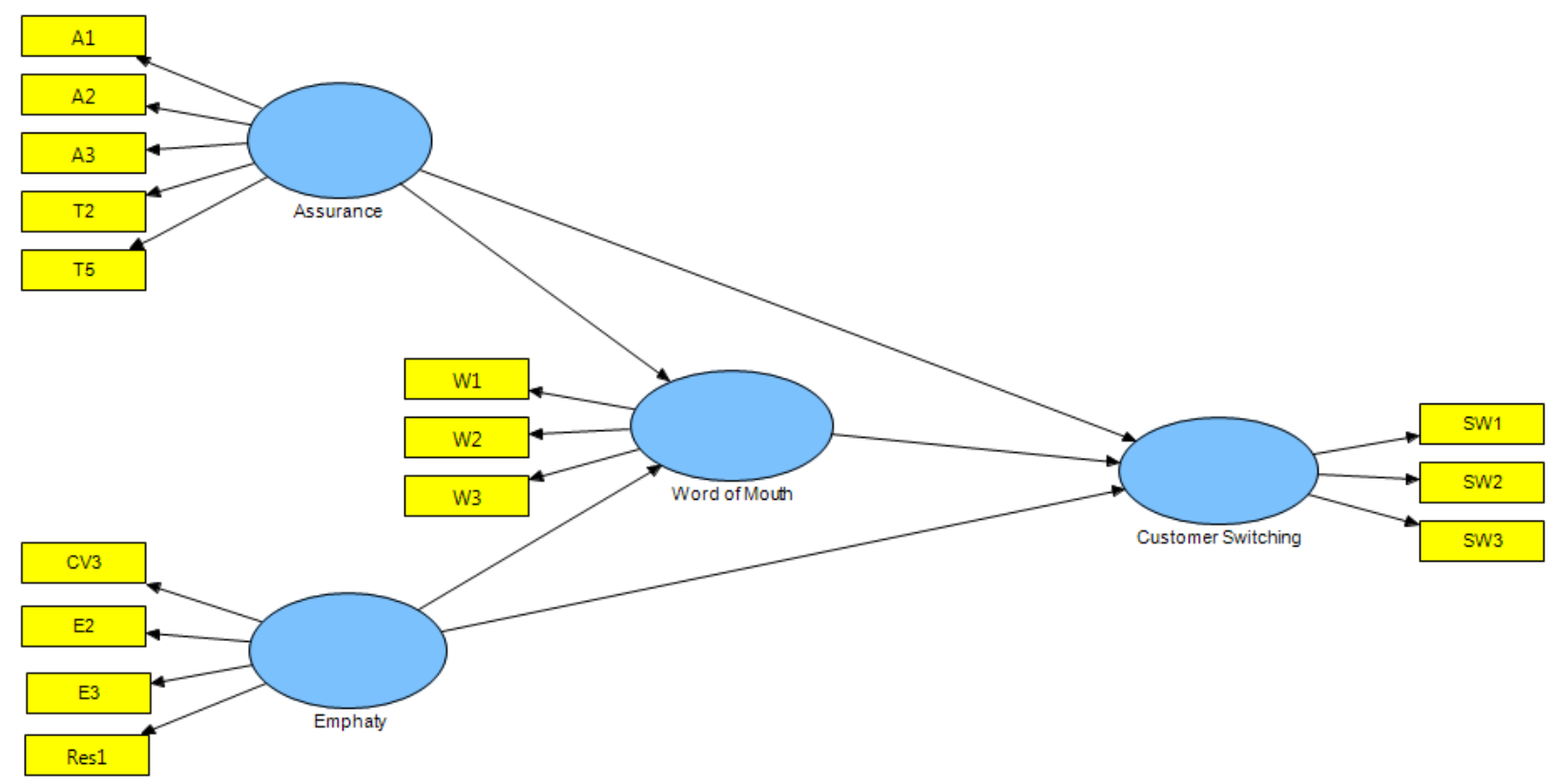

Figure 1. Research Model

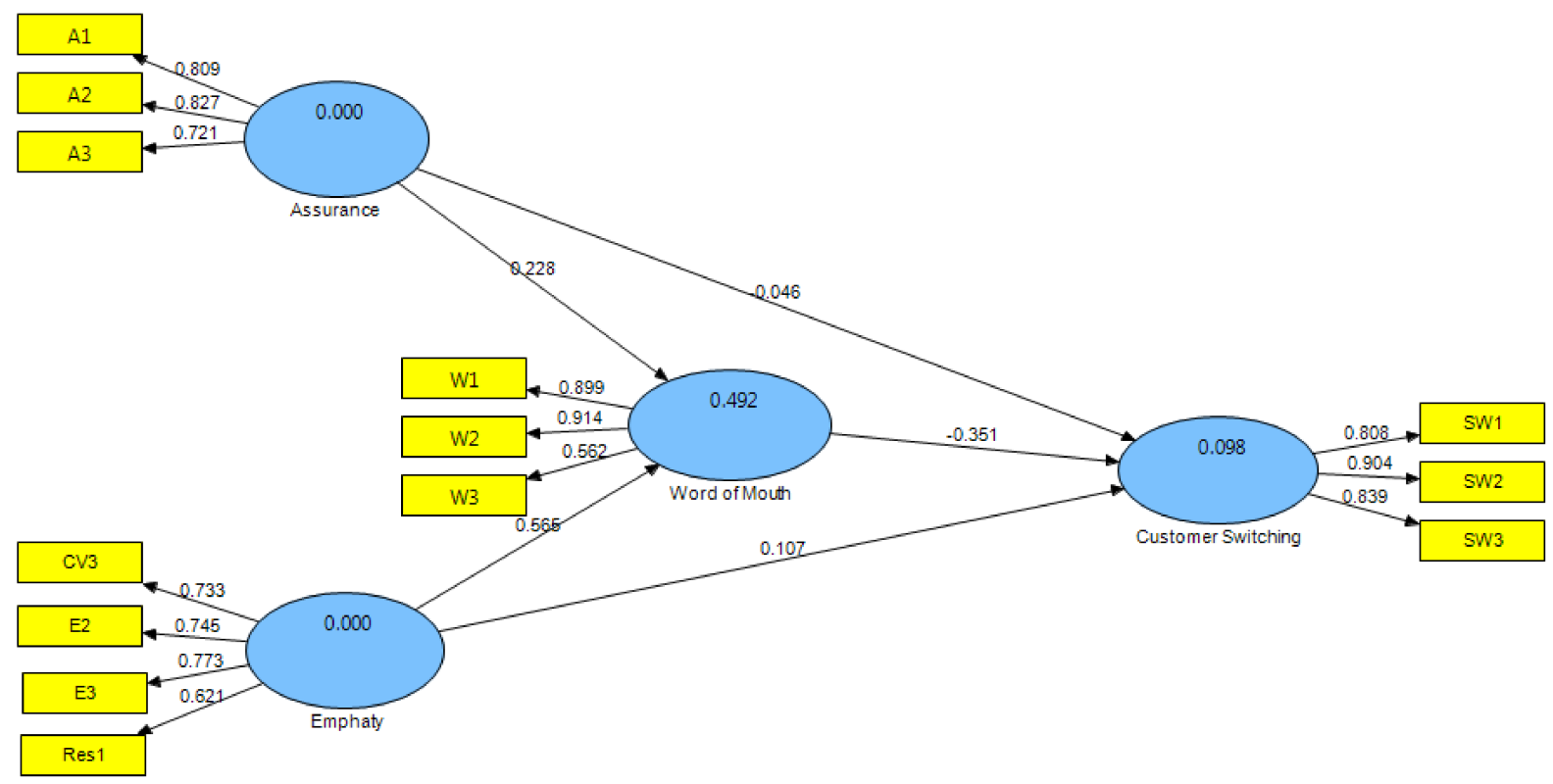

Figure 2. Revised Model 


\subsection{Word of Mouth Communication}

Word-of-mouth communication is defined as "informal communications directed at other consumers about the ownership, usage, or characteristics of particular goods and services and/or their sellers", Westbrook, 1987[9]. Many organisations, especially those that are providing services have long recognized that consumer dissatisfaction with the services rendered to him or her often occur from time to time. This consumer response to service dissatisfaction could be inform of direct complaints to the service provider, personal responses including (service switching and negative word-of-mouth communication) and third party responses to service dissatisfaction, (which include taking legal action as well as filing a case to consumer protection associations.

\subsection{Customer Switching}

Customer switching is defined as an act of being loyal to one service categories (e.g. banking services), but switch from one service provider to another as a result of dissatisfaction or any other related problems, Keaveney, and Parthasarathy, 2001; Sathish, Kumar, Naveen andJeevanant ham, 2011([2],[3]). Previous studies have examined various antecedents of customer switching including pricing, Gerrard, and Cunningham, 2004[10], switching cost, Maiyaki and Mokhtar, 2011[11], customer satisfaction, Moutinho and Smith, 2000[12] and ethical problems, Keaveney, 1995 13], among others. However, despite the large number of studies that examined various antecedents of customer switching, yet, few studies examined these antecedents in banking industry, especially among the customers of deposit money banks.

\subsection{Relationship between Perceived Service Quality and Customer Switching}

Perceived service quality is often conceptualized as a determinant for customer switching behaviour, Kuruuzum and Koksal, 2010); Maiyaki and Moktar, 2012; Kuruuzum, and Koksal, 2010; Zeithaml, Berry and Parasuraman, 1996 ([14],[15],[16]). Several studies have investigated the relationship between dimensions of service quality and customer switching. For instance, Chakravarty, Feinberg and Rhee, 2004[17] found that three service quality dimensions, namely; empathy, responsiveness and reliability had significant negative relationship with customer switching behaviour. Conversely, Chakravarty et al.,[17], found no significant negative relationship between tangibility and customer switching behaviour. Also Alexandris et al[6] found no significant relationship between assurance and customer switching. It is clear that there are inconsistent findings on the relationship between dimensions of service quality and customer switching behaviour. One possible explanation for the inconsistent findings reported on the relationships between dimensions of service quality and customer switching behaviour is that effect of service quality on customer switching depend upon the type of services being rendered by a firm, Babakus and Boller, 1992[18].
Thus, these conflicting findings suggest further studies on the relationship between the two variables are needed. Hence, it is hypothesized that:

H1: Assurance will be negatively associated with customer switching

H2: Empathy will be negatively associated with customer switching

\subsection{Relationship between Perceived Service Quality and Word Of Mouth}

Another important aspect of this study is to examine the effects of dimensions of service quality on word of mouth communication. Previous researches have shown that perceived service quality is an antecedent of word of mouth communication, Barlas, Mantis and Koustelios, 2010; De-Matos and Rossi, 2008 ([19],[20]). Furthermore, several studies have focused on the relationship between dimensions of service quality and word of mouth communication. For example, Chaniotakis \& Lymperopoulos, 2009[21] found a statistically significant positive relationship between empathy and word of mouth. The study by Alexandris et al.,[6] also reveals a significant relationship between assurance and word of mouth communication. On the other hand, Kuo[22] found no significant relationship between service quality dimensions and post-purchased intention in form of word of mouth. Thus, the following hypotheses are formulated:

H3: Assurance will be positively associated with word of mouth communication;

H4: Empathy will will be positively associated with word of mouth communication

\subsection{Relationship between Word of Mouth and Customer Switching}

The relationship between word of mouth communication and customer switching has been documented by the previo us studies. For example, the study of Katz \& Lazarsfeld[23] established that word of mouth communication had a significant negative influence on customer switching decision. Similarly, Dierkes, Bichler and Krishnan, 2011[24] found that word of mouth has a significant negative impact on customer's purchase decisions. Since customer switching is the opposite of customer purchase decision, the following hypothesis is formulated:

H5: Word of mouth communication will be negatively associated with customer switching.

\subsection{Theoretical Underpinning of Study}

In this study, we draw on theory of planned behaviour as an underlying framework for understanding the antecedents of customer switching behaviour. The theory of planned behavior postulates that intention could be the best determinant of an individual behavior, Ajzen and Fishbein, 1980; Ajzen, 1985 ([25-26]). Thus, individual who has a strong intention is likely to engage in the behavior than the one low intention. In the context of consumer behaviour, the 
theory of planned behavior posits that individual's intention is the immediate antecedent of customer switching behaviour. The stronger the individual's intention, the greater the likelihood of he or she will switch from one service provider to another.

\section{Methodology}

\section{1. Sample and Data Collection}

The population of the study consists of 245 customers of selected deposit money banks within Kano Metropolis in North-Western region of Nigeria. The study employs a simple sampling technique, in conjunction with sample selection formula, which is stated as follows, Yamane, 1967[27]:

$$
n=\frac{N}{1+N(e)^{2}}
$$

Where: $\mathrm{n}=$ Sample size; $\mathrm{N}=$ Population of the study; $\mathrm{e}=$ Level of precision.

Based on the above formulae, a representative sample size of one hundred and fifty (150) was chosen from a population of 245 customers of selected deposit money banks, with precision levels of $\pm 5 \%$ and the level of confidence is $95 \%$. Furthermore, out of one hundred fifty questionnaires administered, a total of one hundred questionnaires were completed and returned, representing 66.7 percent response rate.

\subsection{Measurement}

\section{Perceived service quality}

In the present study, Parasuraman, Zeithaml and Berry, 1988)[8] 22-item SERVQUAL scale was adapted to measure the dimensions of service quality. Each of the adapted item was assessed on a 7-point scale ranging from 1 strongly disagree to 7 strongly agree. An example item that was included for SERVQUAL scale is "The bank employees dressed and appeared very neat". SERVQUAL scale was adapted in this study because previous studies, Maiyaki and Mokhtar, 2011; Park, Robertson and Wu, 2006 ([11],[28] have used it and was found to be reliable.

\section{Word of mouth and customer switching}

Both word of mouth and customer switching behaviour were measured using a seven-item behavioural intention scale developed by, Anthanassopoulos, Gounaris and Sathakopoulos, 2001[29]. The items adapted from this scale were assessed on a 7-point scale ranging from 1 strongly disagree to 7 strongly agree. Examples of items that were asked for this behavioural intention scale are "I have encouraged friends and acquaintances to do business with the bank" and "I have decided to switch to another bank that offers better service". Behavioural scale has been adapted and tested by the previous studies and was found to be reliable, Hoq and Amin, 2010; Malik and Naeem, 2011 ([30],[31]).

\subsection{Analysis Method}

Data were analyzed using Structural Equation Modeling (SEM), through Partial Least Square (SmartPLS 2) due to the small sample size, Ringle, Wende and Will, 2005[32].

\section{Results}

\subsection{Demographic Profile of the Respondents}

The demographic profile of respondents in this study shows that $33 \%$ of the respondents were male and the remaining $67 \%$ were female customers. This implies that the number of female customers out-numbered the male. In terms of marital status, $70 \%$ of the respondents were single and the remaining $30 \%$ were married. With regards to educational level majority of the respondents hold Bachelor's degree representing $56 \%$, followed by $22 \%$ of the respondents, who are Masters Degree holders. Furthermore, most of the banks customers included in the study are on temporary employment and only $12 \%$ are on full time employment. (see table 5).

\subsection{Goodness of Measures}

In an attempt to determine the goodness of measures, reliability and validity methods were employed. After calculating PLS Algorism, the report shows that Cronbach's alpha co-efficient ranged from 0.698 to 0.809 (see Table 1). In this study some values of the Cronbach's alpha coefficient are greater than 0.5. According to Sekaran[33], a Cronbach's alpha coefficient greater than 0.5 is deemed to be acceptable. Thus, we conclude that the instrument adapted in this study is reliable since the Cronbach's alpha for each variable is greater than 0.5 . The result in Table 1 also assesses the convergent validity of the instrument used in this study. Table 2 presents the loadings and cross loadings of the constructs after the refinement of the constructs. In this study, the cut-off value is higher than 0.5, Hair, Black, Babin, and Anderson, 2010[34]. Table 2 shows that all the items loaded on their respective constructs ranging from 0.562 to 0.914 . Likewise, the composite reliability value ranges from 0.811 to 0.887 which are greater than the recommended value of 0.5 , Hair et al, 2010[34]. Finally, to justify the discriminant validity, average variance extracted (AVE) is compared to correlation squared of the interrelated variables of concerned, Fornell and Larcker, 1981[35]. Table 3 presents the result of discriminant validity. The result shows that the average variance extracted are greater than the squared correlations. Thus, in this study the measurement model indicates adequate convergent and discriminant validity. 
Table 1. Goodness of measures

\begin{tabular}{|cccccc|}
\hline Construct & Items & Loadings & Cronbachs Alpha & Composite Reliability & AVE \\
\hline \multirow{5}{*}{ Assurance } & A1 & 0.809 & & & \\
& A2 & 0.827 & 0.693 & 0.829 & 0.619 \\
& A3 & 0.721 & & & \\
& CV3 & 0.733 & & 0.811 & 0.519 \\
E2 & E3 & 0.745 & 0.773 & & \\
Switching & Res1 & 0.621 & & 0.887 & 0.725 \\
& SW1 & 0.808 & 0.809 & & 0.653 \\
\hline
\end{tabular}

Table 2. Loadings and Cross Loadings Statistics

\begin{tabular}{|l|l|l|l|l|}
\hline & \multicolumn{3}{|c|}{ Assurance Switching Empathy Word } \\
\hline A1 & 0.808545 & -0.130181 & 0.398163 & 0.447555 \\
A2 & -0.104118 & 0.396401 & 0.328074 \\
A3 & -0.826958 & -0.277939 & 0.308466 & 0.36619 \\
CV3 & 0.721246 & -0.114922 & 0.733405 & 0.525791 \\
E2 & 0.320616 & -0.072228 & 0.745315 & 0.444378 \\
E3 & 0.444004 & 0.150676 & 0.772524 & 0.572439 \\
Res1 & 0.339879 & 0.807534 & 0.621063 & 0.336395 \\
SW1 & 0.233118 & 0.904233 & -0.170769 & -0.265555 \\
SW2 & -0.302944 & 0.838996 & -0.0853 & -0.250984 \\
SW3 & -0.086732 & -0.126667 & -0.124222 & -0.252084 \\
W1 & -0.018303 & -0.121634 & 0.645879 & 0.898933 \\
W2 & 0.413403 & -0.57188 & 0.656765 & 0.914404 \\
W3 & 0.49691 & 0.264011 & 0.561874 \\
\hline
\end{tabular}

Table 3. Discriminant Validity

\begin{tabular}{|l|c|c|c|c|}
\hline & \multicolumn{4}{|c|}{ Assurance Switching Empathy Word } \\
\hline & 0.787 & & & \\
Assurance & -0.169 & 0.851 & & \\
Switching & 0.469 & -0.151 & 0.720 & 0.808 \\
Empathy & 0.493 & -0.302 & 0.672 & \\
Word & & & & \\
\hline
\end{tabular}

Table 4. Path coefficients and hypotheses

\begin{tabular}{|cccccc|}
\hline Hypotheses & $\begin{array}{c}\text { Path } \\
\text { Coefficients }\end{array}$ & Standard Error & T Statistics & P-Value & Decision \\
\hline Assurance -> Switching & -0.046 & 0.226 & 0.202 & 0.420 & Not Supported \\
Assurance -> WOM & 0.228 & 0.084 & $2.705^{* *}$ & 0.003 & Supported \\
Empathy -> Switching & 0.107 & 0.124 & 0.859 & 0.195 & Not Supported \\
Empathy -> WOM & 0.565 & 0.080 & $7.066^{* * *}$ & 0.000 & Supported \\
WOM-> Switching & -0.351 & 0.151 & $2.322^{* *}$ & 0.010 & Supported \\
\hline
\end{tabular}




\subsection{Hypotheses Testing}

This study examines the antecedents of customer switching behaviour in Nigerian banking industry. The interpretation of the hypotheses results is summarized in Table 4. The results indicates that there is a significant positive relationship between assurance and word of mouth ( $\beta=0.228 ; \mathrm{T}=2.705 ; \mathrm{P}=0.003$ ). This finding is in line with the study of Alexandris et al.,[6], thus, H3 is supported. Likewise, the relationship between empathy and word of mouth is found be significant $(\beta=0.565 ; \mathrm{T}=7.066 ; \mathrm{P}=0.000)$. This finding is not surprising, because it is in line with the findings from the previous study, Katz and Lazarsfeld, 1955[23], therefore, H4 is supported. Next, word of mouth had significant negative relationship with customer switching $(B=-0.351 ; \mathrm{T}=2.322 ; \mathrm{P}=0.010)$. This finding is

Table 5. Demographic profile of respondents $(n=100)$

\begin{tabular}{|c|c|c|}
\hline Characteristics & Frequency & Percent \\
\hline Gender & 33 & $33 \%$ \\
Male & 67 & $67 \%$ \\
Female & 70 & $70 \%$ \\
\hline Marital status & 30 & $30 \%$ \\
Single & 5 & $5 \%$ \\
Married & 56 & $56 \%$ \\
Educational Level & 22 & $22 \%$ \\
Undergraduate & 17 & $17 \%$ \\
Bachelor's degree & & \\
Masters degree & 12 & $12 \%$ \\
Doctorate degree & 33 & $33 \%$ \\
Job & $21 \%$ \\
Full-time employment & 34 & $34 \%$ \\
Part-time employment & \\
Contract employment & & \\
Temporary employment & 34 & \\
\hline \multicolumn{2}{|c|}{}
\end{tabular}

Table 6. R Square

\begin{tabular}{|c|c|c|}
\hline & R Square & R Square (\%) \\
\hline Switching & 0.098 & 9.77 \\
\hline Word of Mouth & 0.492 & 49.17 \\
\hline
\end{tabular}

\section{Managerial Implications, Limitations and Suggestion for Future Research}

The major implication drawn from the direct effect of perception of service quality (assurance and empathy) on word of mouth is that banks which provided good service will be freely promoted by positive word of mouth by customers. The findings from this study have been supported by previous studies. It must be acknowledged that this study suffered from some methodological limitations. First, the data for the study were mainly collected from selected customers of deposit money banks in Kano metropolis. Thus, the findings of the study cannot be generalized to the entire banking industry in Nigeria. Second, it is a cross-sectional in nature, because data was collected at one point in time and therefore the direct effects of the independent variables on the dependent variables are difficult to conclude. In order to overcome some of these limitations, future studies should consider the possibility of in line with the previous study, Gounaris and Stathakopoulos, 2001[29], hence H5 is supported. Meanwhile, the result indicates that assurance has no significant effect on customer switching ( $\beta=0.046 ; \mathrm{T}=0.202 ; \mathrm{P}=0.420$ ). This finding is inconsistent with the study of Alexandris et al[6]; hence, H1 is not supported. The relationship between empathy and customer switching does not seem to be significant $(\beta=-0.107 ; \mathrm{T}=0.859 ; \mathrm{P}=0.195)$. This result also is not consistent with the study of Chakravarty et al[17], we therefore reject $H 2$. Finally, table 6 , shows that R-square $\left(\mathrm{R}^{2}\right)$ for the word of mouth and customer switching are 0.492 and 0.098 , respectively. This implies that assurance, empathy and reliability explain $49.17 \%$ variance in word of mouth communication, and $9.77 \%$ variance in customer switching.

increasing the sample size by including more customers of banks in their studies. In addition, future studies should employ a longitudinal research design, so that the direct effects of the independent variables on the dependent variables could be concluded.

\section{Conclusions}

In this study, five direct relationships have been proposed: (1) assurance and customer switching; (2) empathy and customer switching; (3) assurance and word of mouth com munication; (4) empathy and word of mouth communication; (5) word of mouth communication and customer switching. The findings of this study revealed that there is a significant positive relationship between: assurance and word of mouth communication; empathy and word of mouth communicatio $\mathrm{n}$. The study also found a significant negative relationship between word of mouth communication and customer switching. Meanwhile, the study found that there is no significant relationship between: assurance and customer switching; empathy and customer switching.

\section{ACKNOWLEDGEMENTS}

We wish to acknowledge the contribution of Dr. Abdullah Kaid Al-Swidi of College of Arts and Sciences, Universiti Utara Malaysia, who offered many valuable suggestions in the aspect of SmartPLS.

\section{REFERENCES}

[1] Soludo, C. C. (2006). Beyond banking sector consolidation in Nigeria. Retrieved from, http://wwww.cenbank.gov.ng/OUT /SPEECHES/2006/GOVADD29-3-06.PDF

[2] Keaveney, S.M., \& Parthasarathy, M. (2001). Customer switching behavior in online services: An exploratory study of the role of selected attitudinal, behavioral, and demographic factors. Journal of the Academy of Marketing 
Science, 29, 374-90. doi: 10.1177/03079450094225

[3] Sathish, M., Kumar, K. S., Naveen, K. J., \& Jeevanantham, V. (2011). A Study on consumer switching behaviour in cellular service provider: A study with reference to Chennai. Far East Journal of Psychology and Business, 2 (2), 71-81. Retrieved from http://www.fareastjournals.com/files/V2N2P5.pdf

[4] Ernst \& Young (2011). Global banking survey: a new era of customer expectation - Prevent customer attrition.

[5] Choi, K., Cho, W., Lee, S., Lee, H., \& Kim, C. (2004). The relationships among quality, value, satisfaction and behavioral intention in health care provider choice: A South Korean study. Journal of Business Research, 57, 913- 921. doi: 10.1016/j.bbr.2011.03.031

[6] Alexandris, K., Dimitriadis, N., \& Markata, D. (2002). Can perceptions of service quality predict behavioral intentions? An exploratory study in the hotel sector in Greece. Managing Service Quality, 12, 224-31. doi:10.1108/096045202104348 39

[7] Parasuraman, A., Berry, L.L, \& Zeithaml, V. (1985). A conceptual model of service quality and the implications for future research. Journal of Marketing Management, 49, 41-51. Retrieved from, http://www.jstor.org/stable/1251430

[8] Parasuraman, A., Zeithaml, V.A., \& Berry, L.L. (1988). SERVQUAL: A multiple-item scale for measuring customer perceptions of service quality. Journal of Retailing, 64(1), 12-40. doi: 10.1016/S0148-2963(99)00084-3

[9] Westbrook, R.A. (1987). Product/consumption-based affective responses and postpurchase processes. Journal of Marketing Research, 24, 258-70. Retrieved from, http://www.jstor.org/stable/3151636

[10] Gerrard, P., J., \& Cunningham, J. B. (2004). Consumer switching behavior in the Asian banking market, Journal of Services Marketing, 18, 215 - 223. doi: $10.1108 / 08876040410536512$

[11] Maiyaki, A. A., \& Mokhtar, S. S. M. (2011). Determinants of customer behavioural intention in Nigerian retail banks. Interdisciplinary Journal of Research in Business 1(10), 4248. Retrieved from www.idjrb.com/articlepdf/idjrb10n1p5.p df

[12] Moutinho, L., \& Smith, A. (2000). Modeling bank customer satisfaction through mediation of attitudes towards human and automated banking. International Journal of Bank Marketing, 18 (3), 124 - 134. doi: 10.1108/02652320010339 699

[13] Keaveney, S. M. (1995). Customer switching behavior in service industries: An exploratory study. Journal of Marketin g, 59 (2), 71-82. Retrieved from, http://www.jstor.org/stable/ 1252074

[14] Kuruuzum, A., \& Koksal, C. D. (2010). The impact of service quality on behavioral intention in hospitality industry. International Journal of Business and Management Studies, 1 2, (1), 9-15. Retrieved from, http://www.sobiad.org/eJOURN ALS/journal_IJBM/arhieves/2010_1/02ayse_kuruuzum.pdf

[15] Maiyaki, A. A., \& Moktar, S. S. M. (2012). Determinants of customer behavioural responses in the Nigerian retail banks: Structural equation modeling approach. African Journal of Business Management, 6, 1652-1659. doi: 10.5897/AJBM11 .2335
[16] Zeithaml, V. A., Berry, L.L., \& Parasuraman, A. (1996). The behavioural consequences of service quality. Journal of Marketing Management, 60, 31-46. Retrieved from, http://www.jstor.org/stable/1251929

[17] Chakravarty, S., Feinberg, R., \& Rhee, E. (2004). Relationships and individuals' bank switching behavior. Journal of Economic Psychology, 25, 507-527. doi: $10.1016 / \mathrm{S} 0167-4870(03) 00051-5$

[18] Babakus, E., \& Boller, G. W. (1992). An empirical assessment of the SERVQUAL Scale. Journal of Business Research. 24, 253-268. doi: 10.1016/0148-2963(92)90022-4

[19] Barlas, A., Mantis, K., \& Koustelios, A. (2010). Achieving positive word-of mouth communication: The role of perceived service quality in the context of Greek Ski Centres. World Leisure Journal, 52, 290-297.doi: 10.1080/04419057.2010.9674654

[20] De-Matos, C.A., \& Rossi, C.A.V. (2008). Word-of-mouth communications in marketing: A meta-analytic review of the antecedents and moderators. Journal of the Academy of Marketing Science, 36, 578-596. doi: 10.1007/s11747-008-0121-1

[21] Chaniotakis, I. E., \& Lymperopoulos, C. (2009). Service quality effect on satisfaction and word of mouth in the health care industry. Managing Service Quality, 19, 229-242. doi:10.1108/09604520910943206

[22] Kuo, Y. F., Wu, C. M., \& Deng, W. J. (2009). The relationships among service quality, perceived value, customer satisfaction, and post-purchased intention in mobile value-added services. Computers in Human Behavior, 25, 887-896. doi: 10.1016/j.chb.2009.03.003

[23] Katz, E., \& Lazarsfeld, P. F. (1955). Personal Influence: The Part Played by People in the Flow of Mass Communications, New York: Free Press.

[24] Dierkes,T., Bichler, M., \& Krishnan, R. (2011). Estimating the effect of word of mouth on churn and cross-buying in the mobile phone market with Markov logic networks. Decision Support Systems, 51, 361-371. doi: 10.1016/j.dss.2011.01.00 2

[25] Ajzen, I. \& Fishbein, M. (1980). Understanding Attitudes and Predicting social Behavior. Englewood Cliffs, NJ:Prentice Hall.

[26] Ajzen, I. (1985). From intentions to actions: A theory of planned behavior. In J. Kuhl \& J. Beckman (Eds.), Action-control: From cognition to behavior (pp. 11-39). Heidelberg: Springer.

[27] Yamane, T. (1967). Statistics: An Introductory Analysis (2nd ed.). New York: Harper and Row.

[28] Park, J. W., Robertson, R., \& Wu, C. L. (2006). Modeling the impact of airline service quality and marketing variables on passengers' future behavioural intentions. Transportation Planning and Technology, 29, 359-381. doi: $10.1080 / 03081060600917686$

[29] Gounaris, S. \& Stathakopoulos, V. (2001). "Behavioral responses to customer satisfaction: an empirical study." European Journal of Marketing, 35(5/6), 687-670.

[30] Hoq, M. Z., \& Amin, M. (2010). The role of customer satisfaction to enhance customer loyalty. African Journal of 
Business Management, 4, 2385-2392. Retrieved from, http://www.academicjournals.org/AJBM

[31] Malik, M. E., \& Naeem, B. (2011). Banking clients' peceived service quality and behavioral responses. European Journal of Social Sciences, 23, 466-473. Retrieved from, http://www.eurojournals.com/EJSS_23_3_12.pdf

[32] Ringle, C. M., Wende, S., \& Will, A. (2005). SmartPLS 2.0 (M3) beta, Hamburg: http://www.smartpls.de.
[33] Sekaran, U. (2003). Research Methods for Business: A Skill Building Approach (2nd Edition). New York: John Wiley \& Sons, Inc.

[34] Hair, J.F., Black, W.C., Babin, B.J., \& Anderson, R.E. (2010). Multivariate Data Analysis. Seventh Edition. Prentice Hall, Upper Saddle River, New Jersey.

[35] Fornell \& Larcker. (1981). Evaluating Structural Equation Models with Unobservable Variables and Measurement Error. Journal of Marketing Research. 48: 39-50. 